\title{
VIVENDO DO REBOLADO: FEMINILIDADES, CORPOS E EROTISMOS NO SHOW BUSINESS TELEVISIVO
}

Raphael Bispo

\begin{abstract}
Quero ser enterrada de bruços, para que o povo me reconheça. Rita Cadillac, chacrete
\end{abstract}

\section{Introdução}

Este artigo é resultado de uma pesquisa de campo realizada, de maneira esparsa (2009-2011), ao longo de dois anos junto às chacretes, antigas dançarinas dos programas de auditório de Abelardo Barbosa, o Chacrinha, nos anos 1960, 1970 e 1980 na televisão brasileira. ${ }^{1}$ As primeiras dançarinas constituem uma geração de mulheres nascidas em metrópoles brasileiras, como Rio de Janeiro e São Paulo, ao final dos anos 1940 e início dos 1950. Em sua maioria, eram jovens oriundas de camadas populares que encontravam por meio da dança uma primeira oportunidade de trabalho no mundo artístico. Hoje, elas têm por volta dos 60 anos de idade e estão afastadas dos programas televisivos, mas não das artes ou da esfera pública como um todo. Seus nomes artísticos tinham por pretensão aguçar os interesses do telespectador por meio de apelidos com conotação sexual e fantasiosa, como Índia Potira, Cléo Toda Pura, Loira Sinistra e Sandra Pérola Negra.

O trabalho de campo foi feito na cidade do Rio de Janeiro pelos mais diferentes bairros em que habitam as chacretes, numa tentativa de acompanhar o dia a dia de algumas dessas dançarinas. A pesquisa culminou com a redação de minha tese de doutorado (Bispo 2013), que se tornou um relato da trajetória de vida da primeira geração de chacretes moradoras da cidade. O trabalho procurou enfocar o modo como vivem, agem, pensam a sua própria existência e falam sobre ela. Para isso, tratou de inúmeros temas como, por exemplo, as suas experiências ontem e hoje com o mundo artístico; suas aproximações e limitações morais para com o mercado erótico e o bas- 
-fond televisivo; as relações afetivo-sexuais que estabeleceram ao longo de suas trajetórias; suas relações com a parentela; seus processos de conversão religiosa; os dilemas em torno de uma vida sexual ativa; a maneira como experimentam o envelhecimento e mesmo a solidão, entre outros assuntos.

Nesse sentido, o presente artigo pretende focar em um desses nichos analíticos investigados na pesquisa mais geral, debatendo as experiências vivenciadas pelas chacretes a partir da escolha de um tipo de carreira artística em que a sensualidade torna-se um requisito indispensável para o renome. Cabe destacar que, além de auxiliar o apresentador Chacrinha nos programas televisivos, as dançarinas compuseram paralelamente um crescente mercado erótico nos anos 1970, estendendo suas atuações para as boates-revistas, a pornochanchada, os ensaios sensuais e a prática de programas de luxo, ampliando assim seus escopos de atuação por meio de atividades que rendiam a elas dividendos ainda mais altos por conta de seus envolvimentos com a vida artística mainstream propiciada pelo mundo televisivo. ${ }^{2}$

Assim, o texto procura dar um passo atrás em relação ao sucesso e ao estrelato dessas artistas da TV e compreender como chegaram a esse mercado particular. A ideia é analisar os processos de seleção aos quais as chacretes foram submetidas, enfocando principalmente os requisitos necessários para se tornarem mulheres do show business televisivo. O fio argumentativo central a ser aqui traçado e trabalhado etnograficamente é que gênero, corpo e erotismo se entrelaçam na construção da figura televisiva dessas mulheres e se explicitam nos processos que regulam o recrutamento e a exposição de suas imagens. A importância dada à estética corporal das chacretes acionava assim uma plêiade variada de marcadores sociais da diferença (como o gênero, a idade, a cor/raça, a sexualidade, a classe etc.) que, quando em interseção, operavam como critérios de distinção, tornando certos corpos mais desejáveis do que outros, sendo alguns deles alvo de recrutamento e atenção, e outros não, neste contexto das artes populares.

Desta forma, o que me pergunto ao longo deste artigo é, basicamente, quais os requisitos para ser uma chacrete e como eles operam distinções sociais ao instituírem e celebrarem midiaticamente certos tipos de corpos. Perceberemos que tais processos de seleção, ao estabelecerem distinções entre corpos mais ou menos desejáveis mediante padrões estéticos de uma determinada produção cultural dita "popularesca", corroboram na consolidação de um dos movimentos que Butler (2002) procurou iluminar por meio da duplicidade que existe por detrás de sua expressão "corpos que importam" (bodies that matters, no original). Notadamente, o termo consagrado pela autora faz referência à inteligibilidade adquirida ou não por certos corpos a partir de uma "matriz heterossexual", numa discussão que busca desnatura- 
lizar o sexo e questionar certos pressupostos sociais ao fazer referência direta a experiências homossexuais, transexuais, travestis, intersex etc. - corpos estes que colocam em xeque uma coerência entre gênero, sexo e desejo. ${ }^{3}$

O que este artigo pretende, de maneira etnográfica, tornar mais nítido, todavia, é o outro lado da moeda do conceito, justamente o duplo movimento de inclusão-exclusão que a ideia de "corpos que importam" inevitavelmente embute, atentando assim para o destaque que uns corpos adquirem no show business brasileiro por meio da negação de outros, tidos como de menor legitimidade social nesse contexto das artes populares. Além disso, ao final do artigo, tecerei uma breve discussão sobre as convenções normativas de gênero e sexualidade, a partir dos chamados aspectos "transgressores" e/ou "conservadores" da atividade de chacrete, em diálogo com uma bibliografia contemporânea que reflete sobre os feminismos e o papel das mulheres em atividades profissionais diretamente ligadas ao sexo (Rubin 1984; Vance 1984; Gregori 2003, 2012; Piscitelli 2004, 2005, 2011).

Isto posto, destaco que uma das coisas que mais me chamaram a atenção ao longo da pesquisa com as chacretes foram os inúmeros passeios etnográficos que acabamos realizando juntos por revistas, jornais, fascículos de coleções, biografias, autobiografias, cartas, fotografias, vídeos ou qualquer outro tipo de reminiscência sobre a experiência de se ser uma chacrete nos anos 1970. Sempre quando se encontravam a fim de rememorar o passadoseja comigo, seja entre elas mesmas - suas imagens e reportagens ganhavam destaque recorrentemente. Isso tudo demonstrava que a experiência de ser chacrete é, na verdade, quase uma fulguração. É um momento na vida de várias mulheres em que o extremo da novidade de ser artista explode e transborda, chama a atenção, mas não se sustenta por muito tempo. Momentos de efervescência, que parecem não apostar em um futuro. Há poucos planos, sem finalismos. Apenas o instante, o rápido, o imprevisto. $\mathrm{O}$ "ser chacrete" some até mesmo antes de qualquer inscrição na memória do mundo artístico. Assim, por detrás dessa roupagem resplandecente, vívida, do rótulo tão sugestivo e homogêneo de chacrete, começava a perceber que havia na verdade trajetórias variadas, vidas completamente distintas umas das outras, o exercício de serem muitas em múltiplos lugares. O que existia de comum entre elas, portanto, eram apenas suas inquietudes, seus sensos pela mudança e pela diferenciação e, sobretudo, suas sensibilidades e vontade de compartilhar com os outros suas experiências de vida.

Os arquivos e as coleções particulares das próprias dançarinas tornaram-se assim essenciais para o trabalho de campo, sendo bastante utilizados neste artigo para compor a análise de seus processos de seleção. Algumas possuem ainda um vasto acervo sobre o seu passado de dançarina, focado, é 
claro, em suas carreiras. Isto porque, como costumam dizer as competitivas chacretes, "nenhuma de nós guarda foto ou reportagem da outra". A vasta quantidade de material que algumas possuem, quando comparada à de amigas, já nos indica o quanto umas conseguiam mais espaço na imprensa em geral do que outras. Além disso, tais dançarinas "com arquivos" conseguiram manter praticamente intacto quase todo o material que recolheram. A manutenção durante mais de 40 anos de todo o acervo não é algo fácil de se esbarrar, por exemplo, em função das tentativas de apagamento de seus passados por parte de maridos ou demais parentes. São várias as chacretes que tiveram ao longo da vida seus recortes incinerados por cônjuges. Sendo assim, procurei utilizar na pesquisa todo o material que elas compartilhavam comigo a fim de contarem suas vidas e que nos permitem não esgotar, mas sim recompor de forma caleidoscópica alguns rastros dessas trajetórias heterogêneas. Textos e imagens antigos que emergiam em campo assumem neste trabalho o sentido de "inscrições objetivadas", proposto por Kofes (2001:21), não por serem efetivamente mais objetivos do que certos relatos orais supostamente "subjetivos", enviesados, mas por preservarem melhor certa temporalidade difícil de ser captada em outros registros, tornando-se referências para percebermos as dançarinas em seu auge nos anos $1970 .^{4}$

\section{Cruzando diferenças, estabelecendo hierarquias}

Quando a jovem entrou no estúdio da Rede Globo naquele ano de 1969, as pessoas que ali a esperavam não deram muita bola. "Desculpem o atraso, mas Caxias é bem longe". A moça loura causou má impressão, mesmo sendo bonita. Não pelos cinco minutos perdidos, mas porque usava uma roupa comportada, vestido comprido de cor clara, coxas e colo quase inteiramente cobertos. Só o pescoço devia estar de fora. Lembrava uma "crente" ou uma "caipira". Na verdade, o que faltava mesmo era o savoir faire que se percebe de cara. Ela estava ali porque foi indicada pelo tal de Djalma para comparecer ao teste para chacrete, e foi logo dizendo não estar acostumada com essas coisas. O olheiro tinha frequentado inúmeros colégios secundaristas do subúrbio e áreas periféricas do Rio de Janeiro. Seu objetivo era observar os concursos de beleza que neles aconteciam, à caça de meninas interessadas em dançar na TV em troca de uma módica quantia em dinheiro.

"Moça de família, ótima para um escritório", certamente pensou a equipe. Caso não levasse aquela oportunidade, com certeza conseguiria ser atendente no centro da cidade por causa de sua "boa aparência". Isto porque não havia qualquer sinal na jovem de alguma proximidade com aquele 
ambiente. Era muito acanhada e sem qualquer sex appeal. "Bota aquele maiô, a gente precisa ver as suas pernas". A garota enrubesceu. "Minhas pernas? Mas não é para dançar? Eu gosto de dançar". "Então faz um passinho qualquer aí". Soltaram o som, uma música agitada começou a tocar, os refletores do estúdio acenderam. Ela se balançou sem muita sincronia, mas com certa destreza, mexendo as pernas como costumava fazer com as amigas nas horas do recreio da escola ao som de Roberto Carlos, Vanderley Cardoso e companhia. Perceberam logo que com alguns ensaios poderiam aprimorar os passos da estudante. Dura e sem jeito ela não era. A beleza do rosto ajudava. Pelo vídeo do monitor percebia-se que a luz que batia em seus cabelos provocava um efeito sensual, deixando-os platinados como os da Vanderléia, sua "ídola". "Como ficava bem na telinha!".

Impressão negativa inicial revertida. Mas faltava o maiô. Era preciso ver pernas, coxas e, claro, o bumbum. Depois da insistência do amigo do colégio que a acompanhava, a jovem finalmente vestiu-o. A decisão foi unânime, que "boazuda" ela era! "Os pais dela vão vir aqui nos matar depois que souberem que contratamos essa menina". O savoir faire viria com o tempo, sabiam todos da equipe. Ou não, ela poderia largar tudo em breve. A garota começou como dançarina na quarta-feira seguinte ao teste, ganhando cachê por apresentação, sem salário fixo ou carteira assinada, mas com ajuda de custo para passagens, alimentação e vestimentas básicas. Como primeiro emprego, estava ótimo. Ia ganhar um pouco mais do que lia nos anúncios de jornal para secretária ou balconista. A estudante tinha tirado a sorte grande, e ainda por cima ia virar estrela! Mas complicada era a distância entre o bairro Baixo Cavaleiro em Duque de Caxias, cidade metropolitana do Rio de Janeiro onde morava, e o Jardim Botânico, zona sul da capital do estado, sede da Rede Globo. Quilômetros separam as duas discrepantes partes das cidades vizinhas. Pelo menos o centro do Rio era mais perto de sua casa. "Não seria melhor ser mesmo secretária?", se perguntava.

Essa história sobre um teste para dançarina foi inúmeras vezes relatada a mim pela hoje senhora Vera Lucia Ferreira da Silva, 63 anos, mais conhecida como Vera Caxias depois de sua participação durante três anos como chacrete na TV. Como pudemos já notar, a beleza, o interesse pela dança, o corpo e suas formas são marcas que distinguem as chacretes de outras mulheres. Ter certo traquejo e interesse em danças com coreografias marcadas, bem como um pequeno domínio de ritmos populares aprendidos ao longo da vida, como o samba, auxiliava na abertura das portas do mundo artístico a certas jovens, mas o fato de serem consideradas pelos selecionadores de "boa aparência", "atraentes", era mais importante, sendo este 
o primeiro critério, ou pelo menos o mais imediato a ser observado, capaz de desclassificar rapidamente várias candidatas (Bispo 2012, 2013, 2014).

Os diretores da época costumam também enfatizar a necessidade de as jovens possuírem o que chamavam de savoir faire e/ou sex appeal (Bispo 2012, 2013). Trata-se de um modo específico e desejável de elas se portarem durante suas exibições para os telespectadores. As chacretes não devem apenas ter um tipo físico característico, mas evocar a todo instante uma imagem de mulher superexcitada e sempre disponível, servindo-se de seus corpos para isso. Desde o processo de seleção, os produtores já atentavam para gestos, trejeitos e estilos que evocassem tal imaginário. ${ }^{5}$ A estética e a corporalidade, portanto, eram essenciais para a atividade de dançarinas. A vocação está inscrita no físico, na aparência. O corpo é tematizado como imprescindível na definição do que é a ocupação e nas possibilidades de sucesso.

O depoimento de Vera, relatado acima, é também revelador dos diversos critérios que marcavam o recrutamento das chacretes. Gostaria de deter-me agora naqueles que giravam em torno da estética e dos corpos dessas mulheres. Afinal, quais são os atributos e as características físico-corporais considerados fundamentais para se tornar uma chacrete? Veremos o quanto gênero, classe, cor/etnia, sexualidade, idade etc. não existem separados, mas sim "em relação entre si e através dessa relação" (McClintock 2010:19, grifos da autora). ${ }^{6}$ Tais marcadores sociais da diferença podem ser assim traçados, ainda que de modo contraditório e em conflito, a partir deste e de inúmeros outros processos de seleção pelos quais passaram as chacretes, auxiliando-nos a refletir sobre quais eram os corpos mais valorizados nesse contexto específico das artes populares.

Em relação à idade, por exemplo, o mercado de dançarinas televisivas é muito seletivo e tende a considerar velhas as mulheres com 30 anos ou mais. No recrutamento, inúmeras características exigidas das candidatas sempre foram explicitamente enunciadas pelos programadores, como as medidas dos contornos corporais e o tom de pele, mas sobre a idade raramente algo era dito. Ela, no entanto, é um marcador crucial de diferenciação das mulheres, mesmo mantendo-se de certa forma velado nos discursos dos programadores. Isto ocorre porque a juventude é um valor considerado dado, inquestionável. Uma girl velha é algo inconcebível. O próprio uso de termos como "meninas" e "garotas" pela produção para se referir a elas remete ao privilégio dos corpos joviais, considerados mais dispostos e, principalmente, sexualmente mais desejáveis pelo telespectador.

Na maioria dos casos, as chacretes começaram a dançar nas idades mais avançadas que correspondiam ao período ginasial da escola, hoje chamado de Ensino Fundamental II, ou seja, dos 15 aos 17 anos. A ocupação de cha- 
crete era considerada um primeiro emprego, fonte de renda inicial de muitas outras ainda por vir, e não como algo para se estabilizar ao longo da vida. Portanto, a jovialidade da atividade de chacrete se materializa nos próprios rendimentos gerados pelo serviço prestado, algo de baixo valor financeiro para ser executado por mulheres que estavam entrando no mercado de trabalho remunerado e não por pessoas mais experientes. A associação da função de girl ao primeiro emprego de uma mulher oriunda das camadas populares reforça a ideia da existência de uma instabilidade nesta atividade de chacrete, colocando-as sempre à procura de outras oportunidades profissionais, seja no mundo artístico ou não, a fim de se sustentarem. Da mesma forma como ocorre com modelos, manequins e outros ramos do mundo da moda e dos desfiles, a atividade tem um tempo curto e bem delimitado para ser desempenhada (Martinez 2004:218).

Assim, a idade não é só um critério de seleção, mas também um dos principais marcadores que pressionam as girls a se manterem ou não nesta ocupação. Não que explicitamente fossem demitidas por estarem mais velhas, mas as próprias condições do mercado da dança na TV iam dificultando sua permanência nele. Seguindo a proposta de Tereza de Lauretis (1994), inspirada nos escritos foucaultianos, a TV constituiu-se como parte de uma "tecnologia de gênero", na medida em que as compreensões dos indivíduos sobre o masculino e o feminino - bem como as hierarquias que nelas são estabelecidas e que deixam traços na vida social das pessoas e suas imaginações — são perpassadas pelas imagens, os diálogos e as concepções mostrados nos programas televisivos. Estes, assim, produzem um conjunto de efeitos nos comportamentos e nas relações sociais dos indivíduos telespectadores, da mesma forma que engendram respostas, matizes e contraposições a estas representações difusas estimuladas pela comunicação de massa televisionada (De Lauretis 1994:222). Logo, da mesma forma que a televisão estimula certas marcações de gênero, ela acaba também por se constituir como uma espécie de "tecnologia de juvenilização" — parafraseando De Lauretis - enquanto exibe, em boa parte das vezes, por meio de chacretes e outras mulheres, como atrizes, modelos etc., um estilo de vida compreendido como jovial, cedendo muito pouco espaço para a exibição de corpos envelhecidos.

No início da década de 1970, a revista Veja publicou reportagem com as medidas das partes mais valorizadas dos corpos das 19 chacretes que compunham o programa. ${ }^{7} \mathrm{Na}$ matéria havia uma fotografia de cada dançarina e seus respectivos nomes e medidas em legendas, elencando o busto, a cintura e os quadris como alvos especiais da fita métrica do jornalista. A própria revelação dos números e a escolha dessas partes específicas do corpo a serem medidas 
são indícios da distinção que gênero, estética e corporalidades instauram socialmente nesse contexto do mundo artístico popular. A média aritmética das medidas da reportagem revela que o "padrão ideal" de chacrete era de 88 centímetros de busto, 63 de cintura e 100 de quadris. Estes números são emblemáticos e enaltecem um tipo específico de corpo, um corpo "carnudo", como dizia Chacrinha, cujas formas denotam as características hiperbólicas da verdadeira "boazuda": seios pequenos e arredondados, cinturas finas e bem torneadas, coxas grossas e roliças e, principalmente, quadris avantajados, largos, com uma bunda bastante proeminente, símbolo máximo de sua distinção como dançarina e mulher alvo dos desejos alheios.

A ausência de menção à altura das chacretes nesta ou em outras matérias, por exemplo, revela o caráter arbitrário e ao mesmo tempo fundado numa razão específica de certa ordem social, que dá valor a partes dos corpos das dançarinas que importam, conforme o contexto social em que se inserem. "Enquanto ter um corpo bonito se apresenta como algo evidente e naturalizado, [...] a exigência de altura é percebida como uma arbitrariedade: se a primeira condição é qualidade inerente, a segunda se afigura enquanto exigência que vem de fora" (Giacomini 1992:227).

A dimensão de "exagero" que caracteriza as formas corporais das chacretes está sintetizada na importância dada às suas "bundas grandes" no mercado de trabalho de dançarinas. É impensável uma chacrete sem um "bumbum avantajado". O produtor, Leleco Barbosa, filho de Chacrinha, transforma em discurso tais traços da fartura. Segundo ele, as girls de televisão deveriam sempre se enquadrar na categoria das "udas", ou seja, "chacrete nos anos 70 tinha que ser boazuda, bunduda, peituda, coxuda e cadeiruda" (Barbosa \& Rito 1996:119). O sufixo aumentativo "uda" afasta a exigência de magreza, sendo tolerados, em algum sentido, os quilos a mais, compondo com graça o formato corporal exagerado que é marca de uma chacrete. De acordo com Barbosa e Rito (1996), foi o diretor Luiz Veiga que inventou um recorrente bordão nos bastidores do programa na época, "aquela imagem", para se referir aos travellings que começavam na parte de baixo das pernas das chacretes e iam subindo, vagarosamente, até as coxas. "Como as chacretes usavam calcinhas pretas bem curtas, que chamavam de 'trousses', e as imagens insinuavam não existir nada embaixo, não havia quem resistisse" (Barbosa \& Rito 1996:122). O fato do travelling ser interrompido na cintura, não continuando até os seios ou o rosto da dançarina, consolida esta perspectiva de que certas partes do corpo feminino são mais valorizadas no mundo artístico popular do que outras.

O uso por Leleco do adjetivo "peituda" é mais reflexo de sua tentativa de gerar um efeito narrativo impactante em sua fala por meio do sufixo "uda" 
do que realmente os seios proeminentes serem privilegiados nas dançarinas. A média de 88 centímetros nos indica tamanhos menores e mais modestos de seios, em oposição a uma bunda de grande porte, que ultrapassa as marcas da centimetragem, chegando, de forma ideal, a 1 metro. Enquanto em setores da moda as mulheres precisam ter uma harmonia entre seios e quadris, com medidas próximas entre eles (Martinez 2004:218), no campo da dança erótica é valorizada a desproporção, tendo a bunda um tamanho muito maior quando comparada com as partes de cima do corpo feminino.

É importante destacar que, imbricados a essas dimensões da idade e do gênero e em intenso conflito com elas, também operavam critérios de cor no processo de seleção do elenco. Ao longo da pesquisa, conhecendo as girls e vendo fotografias da época, pude perceber que existia uma nítida valorização da "diversidade de cores" no palco, contando assim com a presença de mulheres cujos tons de pele eram considerados os mais diferentes possíveis. A diversidade se expressava inclusive nos apelidos das dançarinas, e em muitos casos faziam referência à sua origem étnico-racial: louras, morenas, mulatas, negras, caboclas, índias etc. A cor poderia constituir o renome da jovem e fazer sua fama. A proposta, sempre, era agradar a maior quantidade de homens telespectadores e oferecer a eles um "cardápio" variado de tipos femininos brasileiros, por isso esse destaque para a multiplicidade de cores, desde que as jovens obedecessem às dimensões corporais, com medidas próximas à tríade numérica 88-63-100. No palco, todas as "cores brasileiras" estariam representadas. Todavia, isto não significava haver a inexistência de privilégios para certos tons de pele. O caráter erótico da atividade de girl televisiva oferecia às louras e às mulatas um maior espaço neste nicho de mercado, como revela o trecho das memórias da mulher de Chacrinha:

Era o próprio Chacrinha que dava a palavra final na escolha das chacretes entre as candidatas selecionadas pela produção. Ele tinha um método peculiar de avaliação: em sua opinião, mulheres brancas não serviam. Chacrete tem que ser loura ou mulata. E ter mais ou menos o mesmo tamanho das outras. Além de saber dançar. Às vezes uma mulher bonita não fotografa bem na televisão e uma feia com charme dá mais certo. É uma química que só acontece diante da câmera de TV (Barbosa \& Rito 1996:119).

A ideia de que "mulheres brancas não serviam" para serem chacretes aponta para um histórico imaginário social brasileiro acerca das mulheres claras como menos sensuais quando comparadas às de pele mais escura (Corrêa 1996:44). "Mulher branca" significa, nesse contexto do recrutamento, garotas de pele clara e cabelos escuros, elementos que, combinados, são considerados 
Figura 1 - Quase todas as chacretes brancas eram louras e, para isto, usavam perucas. "Mulheres brancas" eram desprestigiadas (acervo pessoal da chacrete Índia Potira)

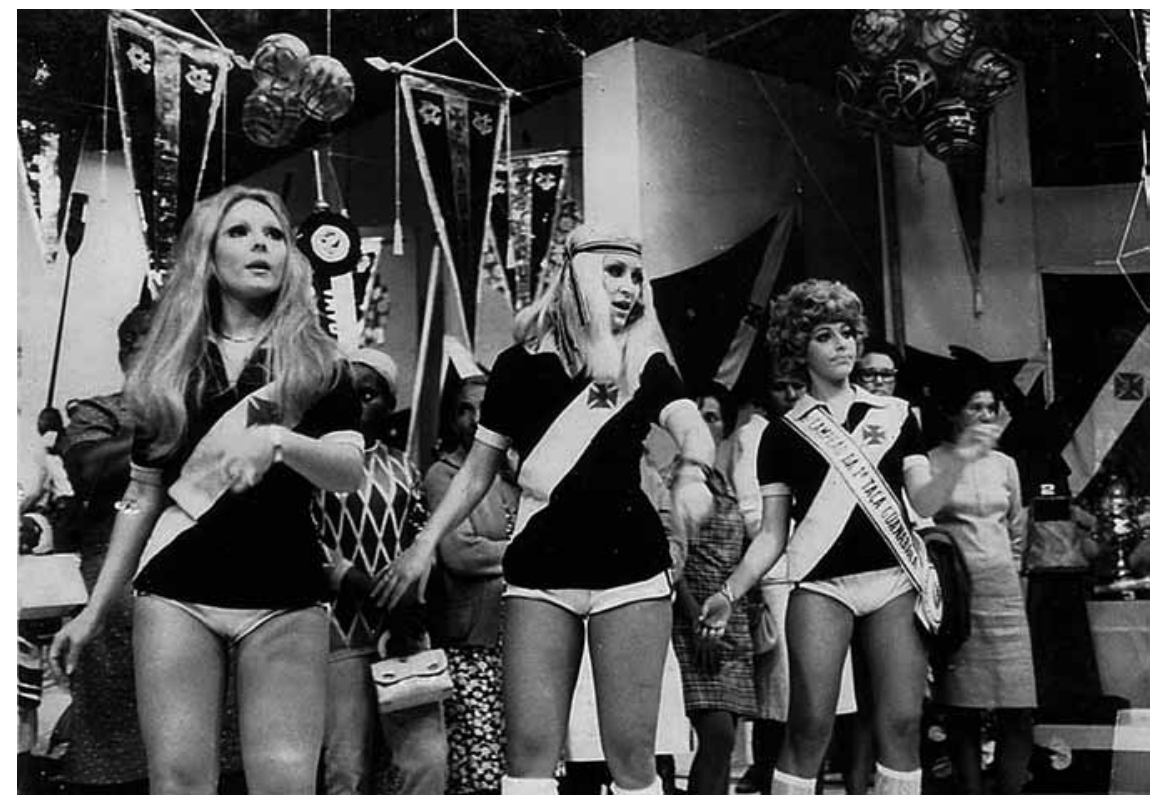

"pouco sexys" no mercado da dança na TV. No entanto, inúmeras chacretes tinham estas características e mantiveram-se na carreira artística com estes traços, o que coloca em xeque a afirmação um tanto categórica de as "mulheres brancas" não servirem para ser chacretes. Tal ênfase procura reforçar a memória de Chacrinha como um pioneiro na valorização da presença de negros na televisão, que sempre tiveram pouco espaço na mídia em geral daquele período.

Todavia, o que é interessante perceber deste desprestígio em relação às "mulheres brancas" é o fato de elas fazerem muito mais uso de perucas louras durante os shows se comparadas com suas colegas de palco com outros tons de pele. O objetivo de tal artimanha era esconder seus cabelos negros durante as apresentações, buscando se tornarem mais desejadas através desse recurso. No final das contas, quase todas as dançarinas de pele clara eram louras no palco. Nas fotografias tiradas durante apresentações nos anos 1970, as "mulheres brancas" são as mais difíceis de serem identificadas hoje, porque são as que menos aparecem com os cabelos ao natural, estando sempre com perucas louras diferentes em cada show, da marca Lady preferencialmente. O uso desse recurso estético dificulta identificá-las nas fotos, algo mais fácil quando se trata das louras "de verdade" e das mulatas, que 
mudavam menos o visual para as apresentações. Nas dinâmicas do palco do Velho Guerreiro, essas "mulheres brancas" - assim como as "negras" (aquelas com as peles mais escuras do elenco) - não costumavam ocupar a linha de frente das dançarinas e eram as que menos tinham apelidos de conotação erótica. Elas ocupavam um espaço cativo no vídeo, sem sombra de dúvida, mas eram menos prestigiadas em vários sentidos quando comparadas a outras mulheres cujo tom de pele era considerado de maior apelo sensual.

Ainda em relação ao trecho da biografia de Chacrinha citado anteriormente, o afastamento das mulheres louras do rol das brancas e sua aproximação das mulatas são indicativos de como essas categorias sociais, só de serem mencionadas, operavam no contexto dos programas de auditório que visavam à transformação dessas mulheres em objetos de desejo sexual, pressupondo em sua própria enunciação a extrema lascívia que tinham seus corpos (Giacomini 2006a:89). Mais: esse deslocamento aponta também para uma compreensão do caráter situacional, ou relacional, de como operam as dinâmicas raciais no Brasil e a definição de cor de um determinado indivíduo (Corrêa 1996:46). Ser considerada loura ou mulata nos programas de auditório era um trunfo, um fator de distinção para uma chacrete, que conseguia mais trabalhos tanto no vídeo como em outras atividades paralelas como dançarinas, incluindo aí fotografias, danças em boates e mesmo fazendo programas. No entanto, o sucesso e a valorização das louras e das mulatas se fazia necessariamente por oposição às "mulheres brancas" e às negras, constantemente desprestigiadas como girls, com destaque bem reduzido.

O sucesso da dançarina mulata "revela a rejeição que essa encarnação esconde: a rejeição à negra preta" (Corrêa 1996:49). Pode-se dizer o mesmo quanto ao esgotamento que as louras provocam nas "mulheres brancas" nesse contexto do mundo artístico popular televisivo. Na escala cromática e contínua que marca a diversidade de cores valorizadas nos programas de auditório, é como se a partir dos polos das peles claras e escuras houvesse matizes mais requisitados, sempre os mais claros destas duas tonalidades: a loura é destaque entre as mulheres de pele clara e as mulatas, entre as jovens de pele escura. Portanto, as mulatas seriam pequenas variações das louras por terem uma coloração de pele mais escura do que elas - o que exemplificava a exaltada miscigenação brasileira - mas longe de serem negras. Para serem consideradas mulatas, as mulheres deveriam ter um tom de pele de cor marrom, mas com traços que as afastassem da mulher negra, ou seja, sem os narizes chatos, os lábios grossos e os cabelos frisados que costumam ser indicativos de negritude (Díaz-Benítez 2010:58). Quanto mais se aproximavam dos traços faciais considerados europeus, mais eram vistas como mulatas e menos como negras, obtendo assim maior sucesso. 
Figura 2 - A Loura Sinistra acompanhada das "indígenas" Lucinha Apache e Índia Potira (acervo pessoal da chacrete Índia Potira)

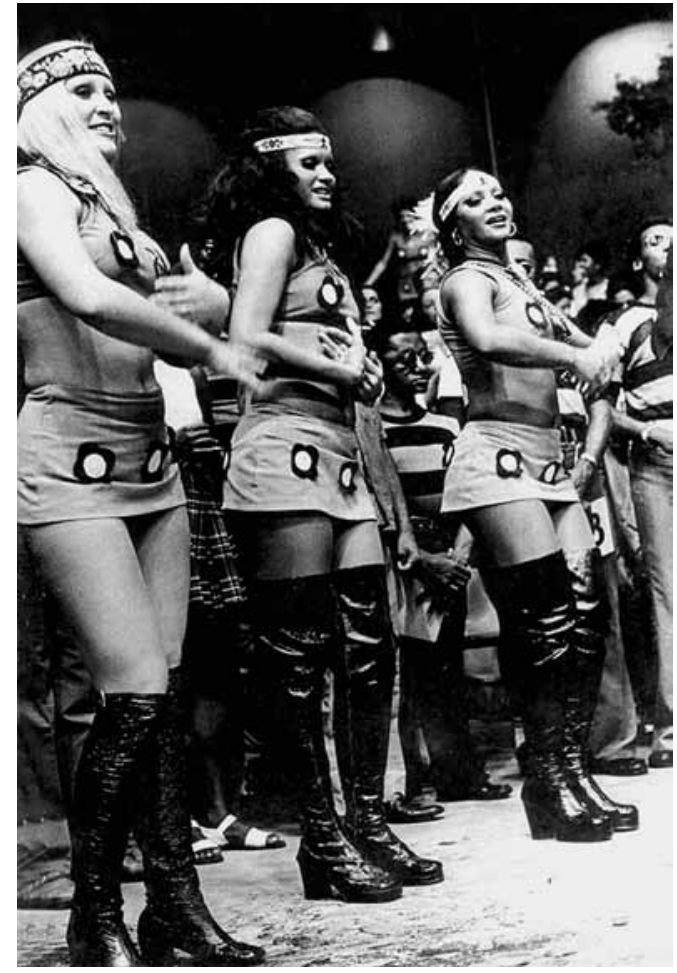

Muitas chacretes famosas tinham suas identificações como dançarinas atreladas a tais traços étnico-raciais. O renome está ligado a uma erotização da cor da pele. Além das louras e das mulatas, pode-se incluir nesse rol do sucesso as dançarinas apontadas como índias. Temos aqui mais um caso emblemático dessa alocação situacional da cor de um indivíduo no Brasil e a importância dada às gradações. ${ }^{8} \mathrm{O}$ limite entre a mulata e a índia era muito tênue, por isso essa possibilidade de destaque das índias e o apreço dado a elas pelos programadores. Compreendia-se a dançarina índia como uma espécie de variação da mulata, tendo apenas os cabelos mais lisos, mas com a mesma cor de pele. A identificação de uma mulher como indígena era uma questão mais contextual do que propriamente identitária, digamos assim. Tornar-se uma índia era uma mera questão de observação e percepção por parte dos programadores de qual era o "tipo" que faltava na composição do elenco de dançarinas. Uma mulata podia se transformar numa índia e vice-versa.

As índias costumavam intercalar trabalhos diversos, ora se apresentando como mulatas - mulatas do Sargentelli ou as "tipo-exportação" (Giacomini 2006b) — ora como indígenas. As jovens "índias" não tinham 
Figura 3 - Angélica, Loura Sinistra, Lucinha Apache e uma outra chacrete desconhecida: "cardápio variado de tipos femininos", segundo Chacrinha (Revista Amiga, Acervo da Biblioteca Nacional)

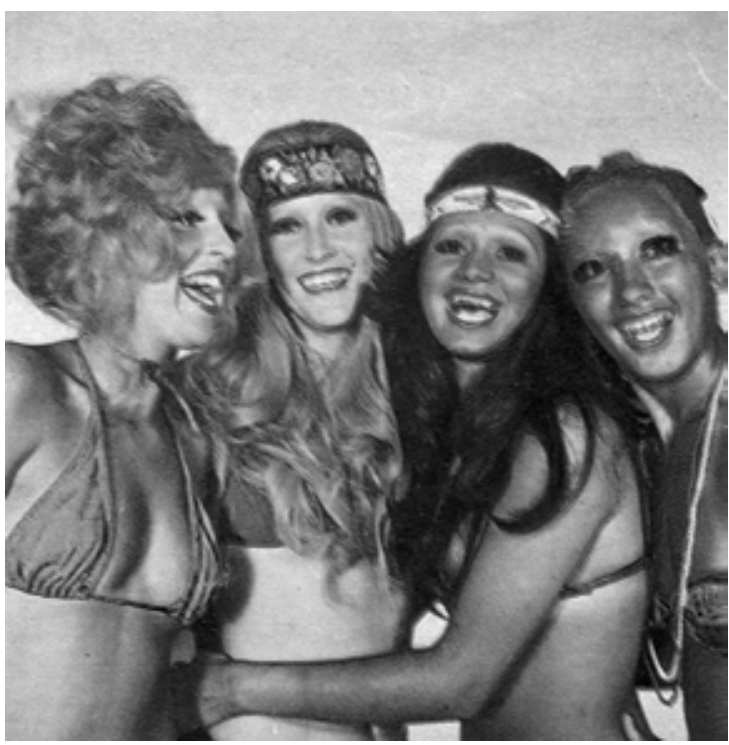

necessariamente este tipo de ascendência, apesar de algumas terem "parentes do norte", o que acabava por creditá-las a esse posto. Nenhuma, ao chegar ao programa, havia se identificado como tal. O tom de pele marrom as aproximava das mulatas, mas eram os cabelos negros e lisos que acabavam por alocá-las no rol das índias do programa, compondo o "cardápio" erótico variado de mulheres e cores que existia no elenco. As mulatas com cabelos mais crespos, para se tornarem índias, costumavam fazer uso de perucas negras e lisas, assim como faziam as "mulheres brancas" para se apresentarem como louras, indicando que eram os cabelos que ditavam a cor da dançarina em certos contextos do programa. Isso acontecia sempre quando faltava no palco alguma mulher de cor mais escura e com cabelos lisos para assumir a personagem indígena no elenco de dançarinas.

A partir dessas interseções, notamos o quanto as atividades das chacretes apontam para as nuances que perpassam as lógicas do gênero, da sexualidade e da raça em nossa sociedade contemporânea. A composição milimétrica que consistia no recrutamento de uma girl pode ser considerada uma faceta de fenômeno mais amplo que Butler (2002:14) nomeou de "esquema regulador de corpos inteligíveis". Temos aqui um processo de pequena dimensão, mas que atualiza em seus próprios termos a maneira como configuramos os corpos que consideramos socialmente dignos e visíveis. Esse recrutamento para ser chacrete demarca, circunscreve e diferencia o que seria um corpo feminino desejável, digno de afeição e elogio, que se constitui 
por meio da articulação e da reificação de concepções mais hegemônicas de idade, gênero, classe, estética, raça e sexualidade presentes em nossa sociedade. A seleção acaba por acionar e propagar dessa maneira discursos que valorizam um tipo específico de feminino. Por exemplo, a bunda é exaltada em sua fartura por sugerir a todo instante disponibilidade para a penetração de um homem. Mais: o corpo louro tem mais oportunidade nesse circuito de desejos, jogando os negros para um segundo plano. E ainda: não há qualquer espaço para a exibição em cadeia nacional de uma girl envelhecida.

Assim, nesse mercado erótico, a seleção e, simultaneamente, a preterição de certos sujeitos-corpos do rol de chacretes em potencial demonstram o quanto essa ocupação se constrói por meio da força de exclusão de outros indivíduos, do repúdio e da hierarquização de certos sujeitos a partir do mero ato de nomear alguns como dignos de atenção e valoração (Butler 2002:20). As chacretes acabam formulando ao redor de si um conjunto de sujeitos-corpos renegados a um segundo plano nas hierarquias dos gostos e dos interesses dos indivíduos, repúdio este sem o qual uma chacrete não poderia surgir como tal. Os processos pelos quais passaram as chacretes favoreceram a hierarquização de corpos a partir da seleção e da exclusão de outros, até mesmo aqueles a princípio desejáveis, como o da loura e o da mulata.

Cabe destacar que, ao utilizar neste contexto o conceito de "corpos que importam" de Butler (2002), apenas procuro por esse duplo movimento de inclusão-exclusão que a ideia embute, enfatizar o relevo que uns corpos adquirem em função da renegação de outros num espaço específico de sociabilidade. Isto porque o conceito é formulado no seio de uma discussão que busca desnaturalizar o sexo, trazendo com ele uma outra faceta, referente ao estatuto da "abjeção" de corpos-sujeitos que destoam de uma "matriz heterossexual". A exclusão social referente à "abjeção" é, portanto, mais "fundacional", digamos assim, e toca em questões centrais de nossa compreensão do mundo e da dignidade ou não que damos à inteligibilidade de certos corpos. A "abjeção", o "corpo que pouco importa" por não ser inteligível, legítimo, geralmente se refere à materialidade de corpos de homossexuais, transexuais, travestis, intersex etc. Eles colocam em xeque a coerência entre gênero, sexo e desejo, além de se verem como espectros que servem de legitimação ao privilégio de outros corpos que de certa forma satisfazem à normatização heterossexual.

Não pretendo dar espaço aqui a esta outra discussão em torno da matriz heterossexual que os conceitos "corpos que importam" e "abjeção" também incluem, apenas pensar o quanto processos como esses pelos quais passam as chacretes favorecem a hierarquização de corpos a partir da escolha de uns e da exclusão de outros. A seleção das chacretes não marca os corpos não escolhidos para o programa como "abjetos" ou ilegíveis, mas estabelece 
distinções e hierarquias de acordo com critérios para o sucesso no show business televisivo. A própria Butler nos dá a pista sobre o movimento de repúdio quando escava a origem do termo abjeção, dizendo ser ele "a ação de lançar fora, descartar, excluir", também designando "uma condição degradada ou excluída dentro dos próprios termos da socialidade" (Butler 2002:19-20, tradução do autor).

A noção de beleza que percorria os bastidores dos programas de auditório nos anos 1970 nos ajuda a ponderar e a pensar sobre os limites desses "corpos fartos" selecionados e exaltados, permitindo-nos constatar o que eles alcançavam em termos de estrelato. Se, por um lado, vemos que eles são capazes de excluir, por outro, percebemos o quanto eles podem ser excluídos. Como destaca Pontes (2009:141-142), a beleza — seguindo, é claro, a relatividade dos padrões estéticos de uma época - é pouco levada em consideração nas análises antropológicas das trajetórias femininas e nas carreiras artísticas, apesar de ser um fator tanto positivo, de estímulo à conquista de alguns espaços, como negativo, por impedir certos voos profissionais e gerar muitos preconceitos. A autora nota que o meio teatral vê com ressalvas mulheres muito belas, na medida em que tal característica pode ser um empecilho ao desempenho múltiplo e variado de sua capacidade interpretativa. Ser considerada como não tão bela assim pode garantir maiores possibilidades de papéis para uma atriz de teatro graças às convenções e às linguagens que regem esse mundo artístico, nos mostra Pontes (2004), superando certas adversidades como a pouca instrução escolar, algo que ocorreu, por exemplo, ao longo da trajetória teatral de Cacilda Becker (Pontes 2004). Ainda segundo Pontes (2004), ela era considerada por muitos de seus pares como "sem grandes atrativos", de "atributos físicos pouco favoráveis", o que lhe permitiu variar seus papéis ao longo da carreira.

No caso das chacretes, a estética é crucial para a ascensão na carreira artística de dançarina, diferente do teatro moderno. O impacto visual provocado por elas é um primeiro requisito de seleção. Porém, é preciso fazer uma ressalva em relação ao fato de que os "corpos fartos" e "arredondados" das girls que tanto chamam a atenção não são necessariamente compreendidos como belos. A "boazuda" pode ser sexualmente desejável e merecer espaço na telinha devido apenas às medidas de seu corpo, mas não é considerada propriamente uma pessoa bonita. Ser uma chacrete bonita é ter um rosto considerado fino, delicado e harmonioso, cujos traços são identificados como "europeus". A beleza não está nas formas da fartura por si mesmas, mas na conjugação destas com traços faciais considerados perfeitos.

Dessa forma, mesmo com a eleição das louras e das mulatas como os perfis femininos mais desejáveis pelos produtores e que melhor combinam 
no vídeo, as de pele mais clara eram sempre consideradas as mais bonitas do elenco, sendo privilegiadas com o close de seus rostos pelas câmeras. Quando se fala até hoje de uma chacrete que "era linda", "muito bela", na maioria das vezes faz-se referência a uma loura e não a uma mulata ou índia. A loura chacrete Débora Lúcia, por exemplo, é sempre assim descrita pelas amigas e pelos produtores. Reportagens da época destacavam que ela "foi capa de quase todas as revistas semanais brasileiras e é a que mais aparece em close, pois é considerada a mais fotogênica". ${ }^{9}$ As chacretes costumam também identificar antigas colegas suas como feias ou "nem tão bonitas assim", que ocupavam a vaga de chacrete apenas por terem "uma enorme bunda". Na maioria das vezes, as mulheres consideradas como feias são a "mulher branca", a negra ou mesmo a mulata, mas raramente a loura. Nesse mercado competitivo da estética televisiva popular, as dançarinas, hoje, costumam apelidar algumas amigas de "raimunda", ou seja, uma "mulher feia de cara mas boa de bunda", na maioria das vezes esse nome sendo utilizado para se referir às mulatas e às negras.

Além disso, esse estilo de beleza das girls é visto por muitos como vulgar e não tinha espaço em outros setores do mundo televisivo, restringindo tais mulheres aos programas de auditório e humorísticos, cujas marcas do "popularesco" eram mais explícitas. Um movimento em prol da conquista de um público telespectador considerado realmente consumidor na Rede Globo de meados dos anos 1970 - cujo padrão de qualidade tinha como meta central afastar qualquer marca que remetesse à cultura popular brasileira, introduzindo na emissora uma "estética de classe média"10 — dificultava o acesso dos corpos das chacretes às telenovelas, por exemplo. Exigia-se das atrizes feminilidade "elegante", "sobriedade", "estilo", "porte", "magreza" e "bom comportamento" — cujo exemplo maior é a "namoradinha do Brasil", Regina Duarte (Almeida 2012) — no máximo uma sensualidade comedida à la Sonia Braga, o oposto do erotismo tido como vulgar das dançarinas oriundas de camadas populares. ${ }^{11}$

Se, para elas, seus corpos eram uma espécie de "porta de entrada" para a televisão, eles operavam também como empecilhos para se galgarem novos patamares dentro desse veículo, principalmente quando o domínio de certo capital cultural seria exigido delas em outras funções. Associadas a uma ocupação pouco prestigiada de dançarinas, a beleza e a fartura das carnes configuravam-se como um entrave para a ampliação de suas possibilidades artísticas na TV, já que esse biotipo estava vinculado tanto ao "popularesco" quanto à superficialidade intelectual.

No outro lado da carreira artística dessas mulheres, quando elas começam a encontrar entraves em certos segmentos da TV por serem "boazudas", 
a cor e o gênero são a todo momento referidos pelas questões de classe, estando a pobreza associada a um determinado estilo de mulher, de formas corporais avantajadas e de capacidade intelectual diminuída. Logo, vemos que as alterações de contexto incidem nos significados atribuídos a tais corpos fartos, isto é, as fronteiras dos "corpos que importam" não são estanques. Os corpos "carnudos" perdem sua positividade e o destaque adquirido nos programas de auditório quando tentam acessar outros nichos do mundo artístico, por exemplo. Qualidades negativas, como a falta de inteligência, a vulgaridade e uma estética na qual fartura vira gordura, são a elas associadas e passam a ser lidas como adversidades e não mais como qualidades. As convenções artísticas das telenovelas, do cinema mais mainstream e mesmo do teatro moderno são pouco afeitas às imagens corporais das chacretes, ressignificando tais corporalidades erotizadas e outrora positivas como algo um tanto pejorativo, execrável.

Nos deslocamentos de contexto pelos quais as chacretes procuraram trafegar nas artes, temos o que Piscitelli $(2007,2011)$ convencionou chamar de "corporalidades em confronto", na medida em que os significados atribuídos a certos sujeitos-corpos variam conforme o contexto em que estão inseridos, sendo as suas características a todo instante cotejadas com os estilos e as convenções corporais que regem os mais diferentes espaços. Se em alguns momentos os "corpos fartos" excluem outros corpos e reafirmam certas normas do que é ser "boazuda", em outros são eles os colocados de lado em prol de corpos que satisfazem distintas convenções hegemônicas, o "corpo belo".

Até mesmo na seara dos programas de auditório, em torno dos anos 1980, os corpos das dançarinas passaram por uma reconfiguração valorativa, ganhando bastante espaço aqueles que confrontavam os estereótipos da girl principalmente por meio de uma ressignificação baseada em questões de classe e na aquisição de capital cultural. Gostaria de me deter agora na articulação da classe social com esse emaranhado de marcadores sociais da diferença que compõem uma chacrete, afinal, foi o fator classe social o que mais se transformou ao longo dos tempos e impôs limites ao chamado "corpo farto". Dizendo de outra forma: se a juventude, os variados tons de pele e o gênero foram marcadores que sempre definiram o que é ser chacrete ao longo dos vinte anos em que estiveram na televisão, a origem social das girls foi o quesito mais reconfigurado ao longo dos anos. No início dos anos 1970 havia a forte presença de "mocinhas suburbanas cariocas" (Barbosa $\&$ Rito 1996:122) que ocupavam esta atividade como um primeiro emprego de baixo rendimento. Já nos anos 1980, quando a ocupação havia ganhado maior visibilidade e tornara-se alvo de menos preconceito - o que não significava maiores salários - muitas mulheres Brasil afora "sonhavam" em 
ser chacrete e, principalmente, em virar artista de TV. Havia no palco cada vez mais a presença de garotas oriundas das camadas médias da sociedade, em especial de São Paulo, cidade em que Chacrinha passou a gravar os programas no período de ostracismo em sua carreira, após as sucessivas demissões da Rede Globo, em 1973, e da TV Tupi, em 1976, ambas no Rio.

A chegada ao elenco de Bia Whitaker, ou Bia Zé Colmeia, é um exemplo importante desse movimento de ampliação das origens sociais das dançarinas e de reconfiguração do programa. Oriunda de uma família considerada "tradicional" de São Paulo, a jovem começou a dançar na "Discoteca", no ano de 1980, na TV Bandeirantes, e lá ficou por quatro anos. A mãe costumava acompanhá-la às gravações, apesar de na época ter sido especulado um intenso conflito no seio da família Whitaker com a atitude de Bia. ${ }^{12}$ Seu estilo de dançar era considerado "irreverente", "original" e um tanto "estranho", sendo especialista não no samba, mas no break. Bia era muito alta e parecia um tanto "desengonçada". ${ }^{13}$ Ela e outras dançarinas desse período já frequentavam a universidade e faziam inúmeros cursos de dança e preparação física, introduzindo novos estilos musicais e de movimento ao programa.

Na revista Homem, em que posou pelada no ano de 1980, a chacrete Dayse Bianco, ou Dayse Cristal, também de família de classe média, foi assim descrita pelos editores da revista, entre uma foto e outra nua:

\footnotetext{
Vejam vocês o que esta mulher, que aparece despretensiosamente nos programas do Velho Guerreiro, faz nas horas vagas: ginástica, para manter a forma, e psicologia, para manter a cuca sempre em dia. Dayse é formada em balé clássico pelo Teatro Municipal de São Paulo, já estudou dança moderna, oriental, jazz e expressão corporal. Ela é formada em Psicologia Clínica pela Faculdade São Marcos, e está terminando o curso de Psicologia Educacional. Dayse tem 27 anos. Uma cabeça ótima (Homem, n. 27-B, p. 62, 1980).
}

Além de serem um pouco mais velhas, as dançarinas oriundas das camadas médias tinham sempre seus sobrenomes mencionados, sendo o apelido erótico jogado para segundo plano pelos programadores em prol de uma valorização não só de seus corpos, mas de suas "cucas", de seus cursos de preparação e profissionalismo. Chegavam à TV após inúmeros cursos de dança ao longo da juventude e se, aos 27 anos, algumas chacretes da primeira geração eram tidas como velhas, as mais abastadas dos anos 1980 conseguiam adentrar o mundo artístico com essa idade e nele ficavam até metade dos 30. Existia um apreço do Velho Guerreiro pela presença dessas mulheres no palco, que se não chegavam a ser maioria do elenco, ofereciam legitimidade à ocupação e estimulavam um maior contato do apresentador 
com as camadas médias da sociedade brasileira, sempre reticente e crítica quanto ao seu estilo "popularesco" e voltado para ritmos musicais como o samba. Tanto é que foi nessa mesma década que Chacrinha começou a ser valorizado pela intelligentsia como um grande comunicador das massas, fazendo palestras em faculdades de jornalismo e se tornando paraninfo em formaturas. $\mathrm{O}$ apreço do meio intelectual pelo apresentador, que se intensificou nesse período, tinha reflexo na maior presença de dançarinas de camadas médias em seu palco e na importante mediação que elas faziam com segmentos sociais mais críticos ao estilo clown de Chacrinha.

Não se pode negar que o movimento de entrada de dançarinas de camadas médias foi explicitamente orquestrado pela produção de Chacrinha. A "mudança" do perfil passou a ser incentivada como uma forma de qualificar a ocupação de chacrete e questionar certos preconceitos. As novas "aquisições" eram consideradas mais preparadas (nenhuma entrava sem experiência), inteligentes (confrontando o estereótipo da girl burra) e profissionais (menos interessadas em se exibir na mídia). Em contraposição direta às chacretes da primeira geração, nos anos 1980 o apresentador ia à imprensa e declarava que "agora, depende muito da mulher respeitar o seu emprego, o seu trabalho. As chacretes de agora são de respeito, não preciso nem recomendar, elas sabem". Sobre os critérios de seleção, não se referia mais às jovens com termos chulos, como "carnudas" ou "boazudas", mas sim com eufemismos e diminutivos, como "certinhas" e "fotogênicas". ${ }^{14}$ E mais:

Hoje as chacretes nem bebem, nem transam tóxicos, pode ser que em outras épocas sim. Elas entram caretas (risos). O mais normal seria tomar uma, duas, três doses de uísque para relaxar, mas isso todo mundo toma. Graças a Deus nós chegamos a um ponto muito bom em termos de chacretes. Hoje, elas são de um nível cultural superior (Homem, n. 27-B, p. 8, 1980).

\section{Feminismos e memórias subterrâneas}

O estilo sexualmente provocante das chacretes coloca em xeque dilemas em torno das feminilidades e dos feminismos na contemporaneidade, bem como os limites da transgressão e do conservadorismo nas práticas de dançarinas eróticas. Gostaria de terminar este artigo refletindo um pouco sobre as normativas de gênero e sexualidade em torno da carreira de girl. Vimos que os corpos das chacretes ora se destacam, ora são preteridos no mundo televisivo, dependendo muito do tipo de produção cultural em que eles se engajam (programas de auditório, humor, telenovelas, telejornais etc.). 
Esse debate pode ser ilustrado através das discussões sobre as chamadas "guerras sexuais" (sex wars, em inglês) analisadas tanto por Rubin (1984), a partir do contexto americano dos anos 1980, quanto por Gregori (2003) e Piscitelli $(2004,2005)$ no Brasil de hoje. O conceito de "guerras sexuais" é recorrentemente utilizado nos estudos feministas para se referir aos debates, às tensões, ressignificações e fissuras das normatividades de gênero e sexualidade que o sexo e as práticas sexuais propriamente ditas podem suscitar em uma determinada cena pública. A análise de Rubin (1984), por exemplo, se concentra na tentativa de nos mostrar que os atos sexuais e a sexualidade promovem diferentes valores e podem ser hierarquizados por meio do estabelecimento, no plano cultural, de uma linha divisória entre o "bom" e o "mau" sexo. A esse fenômeno a autora dá o nome de "estratificação sexual" (Rubin 1984:287). Essa linha divisória é traçada como se separasse a "ordem" do "caos" social; uma vez estabelecida, deveríamos agir como se fosse necessário impedir que tal distinção se rompa. Para a autora, a transformação industrial no Ocidente trouxe novas formas de estratificação social que envolveram mudanças nas desigualdades de classe, gênero, "raça", etnia e, também, sexuais.

No caso da estratificação sexual propriamente dita, uma série de aparatos legais e mesmo controles sociais extralegais passaram a caracterizar algumas práticas ligadas ao sexo como um vetor de opressão. Por isso a necessidade, para Rubin, de chamar a nossa atenção para os períodos históricos em que a sexualidade aparece como mais politizada, conduzindo a complexas renegociações sociais e morais, como se a linha do "bom" ou do "mau" sexo estivesse nesses momentos sendo tensionada, a ponto de promover modificações nessas fronteiras/ demarcações. "O sistema sexual não é uma estrutura monolítica e onipotente. Há contínuas batalhas acerca das definições, avaliações, arranjos, privilégios e custos do comportamento sexual. As lutas políticas sobre o sexo assumem formatos característicos" (Rubin 1984:294, tradução do autor).

A ideia de uma "guerra sexual" foi também utilizada por feministas para se referirem aos inquietantes debates ocorridos no final dos anos 1970, um momento particularmente significativo na história do ativismo americano e cujos efeitos provocaram uma reconfiguração do campo teórico dos estudos de gênero e sexualidade. De acordo com Gregori (2003:101), em meio à ameaça da retomada de "moralidades tradicionais" por intervenção da New Right, ${ }^{15}$ surgiram no cenário feminista grupos bem antagônicos em relação ao estatuto legal que a pornografia e a prostituição deveriam assumir no país. Em 1976 foi criado o Women against Violence in Pornography and Media e, em 1979, o Women against Pornography. Um ano antes, em 1978, nascia o primeiro grupo lésbico sadomasoquista, chamado Samois. 
Interessante notar aqui que nesta "guerra sexual" entre pessoas ligadas aos movimentos sociais em defesa da mulher - e seguindo ainda a análise de Gregori — os conflitos em torno da pornografia e da prostituição catapultados por uma política de governo moralista fizeram emergir, de um lado, posições feministas antissexo - algo "não menos normatizador do que a retórica que caracterizava a New Right" (Gregori 2003:101) — e do outro, comunidades/ grupos que procuravam legitimar apostas e alternativas sexuais, como o sadomasoquismo. Contudo, dessas confrontações e disputas surgia apenas a certeza de que a sexualidade é mesmo uma questão política a ser debatida e enfrentada no domínio público durante certos períodos da trajetória de um país.

Assim, uma crítica comum oriunda desses segmentos feministas contrários à pornografia e feita a mulheres que desempenham atividades no mercado erótico, tal como as chacretes - mas particularmente prostitutas - é de que essas mulheres e os processos de seleção a que são submetidas personificam as objetificações e as subordinações típicas de sociedades consideradas machistas, como a brasileira, ou de forma mais ampla, as latinas. "Devido ao fato de a sexualidade ser um elo do relacionamento entre os gêneros, muito da opressão das mulheres é suportada, mediada e constituída por e através da sexualidade. O Feminismo sempre esteve vitalmente interessado no sexo" (Rubin 1984:300-301, tradução do autor). Seriam as dançarinas, segundo esta perspectiva, a representação eficaz de uma feminilidade que serve aos interesses das hierarquias sociais e da perpetuação da desigualdade entre os gêneros, produtos descartáveis de uma lógica social sexista. Ao se mostrarem ao público como mulheres dedicadas a cortejar o interesse masculino por meio de um comportamento sexualizado, reforçariam as chacretes a visão, por exemplo, de que é dever das mulheres serem belas e submissas para se tornarem desejáveis? As chacretes reafirmam, portanto, concepções hegemônicas sobre o papel dedicado tradicionalmente às mulheres, "um objeto sexual, um ser passivo e carente de poder"? (Piscitelli 2005:13).

Por outro lado, poderíamos pensar também as chacretes como libelos do feminismo, observando a sexualidade como um campo possível para as subversões, servindo para retirar mulheres da subalternidade e não para jogá-las nos porões da "dominação masculina". O sexo pode ser fonte de prazeres e poderes, e não apenas de perigos, dizia Vance (1984). As chacretes exemplificariam a máxima da mulher que possui total controle sobre seu corpo, utilizando-o a seu bel prazer, sendo ela agente de sua própria história, subvertendo e não confirmando a lógica social sexista. Assim, as chacretes seriam exemplos de "pequenos feminismos", sem grandes bandeiras ou batalhas, mas praticados nas linhas de frente da família, do mercado de trabalho e da convivência com a vizinhança? Elas não seriam bons exemplos 
de sujeitos que violam expectativas sociais hegemônicas, "símbolo da autonomia sexual das mulheres e, como tal, uma ameaça potencial ao controle patriarcal sobre as sexualidades"? (Piscitelli 2005:13-14).

Ora, observando por estes dois lados e por tudo que vimos aqui nos processos de seleção das chacretes, há nas práticas das danças eróticas algo de "transgressor" e de "conservador", afirmariam alguns. Muito do que poderia ser apontado como revolucionário nos atos das chacretes no mundo artístico logo em seguida seria criticado pela incitação a moralidades consideradas retrógradas, diante de práticas tidas como as mais machistas possíveis. "O sexo é visto como uma tática cultural que pode tanto desestabilizar o poder masculino como reforçá-lo", nos fala Piscitelli (2005:14). Logo, precisamos fugir desses essencialismos argumentativos, porque a sexualidade é um campo de tensões e disputas, e não de respostas prontas. O sexo, as dinâmicas do erótico podem tanto reforçar quanto contestar certos pressupostos sociais apenas por meio de um único ato. "O foco somente no prazer e na gratificação ignora a estrutura patriarcal na qual as mulheres devem agir. Contudo, falar apenas em violência sexual e opressão ignora, por sua vez, as experiências das mulheres com a agência sexual e a escolha e involuntariamente incrementa o terror sexual e o desespero em que muitas mulheres vivem " (Vance 1984:1, tradução do autor).

Nesse sentido, a polarização dessa argumentação só confunde ao invés de esclarecer. Nada é por si só "revolucionário" ou "conservador", "feminista" ou "retrógrado", muito menos as chacretes tinham pretensões de ser algo desse tipo, tanto por um lado quanto por outro. Elas construíram, assim, um modelo de erotismo que combina alguns traços do que Gregori (2003, 2012) cunhou de "erotismo politicamente correto" em pesquisas sobre sex shops e saúde sexual - indicando a captura e o controle de certas lógicas disruptivas do erotismo quando no contexto do mercado e do consumo capitalistas - com a transgressão e a afronta a certas normativas de gênero e sexualidade que rondam a vivência de muitas mulheres heterossexuais de camadas populares, cujas carreiras de gênero tendem a ser desestabilizadoras e não convencionais, como a de muitas chacretes (detalhes sobre tais trajetórias particulares em Bispo 2013).

$\mathrm{O}$ "erotismo politicamente correto" das dançarinas parece ter como proposta consolidar a perspectiva de que não há nada de transgressor e muito menos uma "intenção deliberada de violar tabus morais e sociais" (Gregori 2003:94) em suas práticas. Insinuam-se nessa clara intenção a conquista de mercado típica de empreendimentos da indústria cultural e a reafirmação de uma fronteira recorrente em nosso imaginário entre as proibitivas e execráveis imagens "pornográficas" — um conceito mais carnal, sensorial e explícito da 
nudez, o "mau sexo" de Rubin (1984) - em oposição às aceitáveis imagens "eróticas", que exibiriam o "sensual" para deleite e elogio do belo, algo que tenderia "ao sublime, espiritualizado, delicado, sentimental e sugestivo" (Leite Jr. 2006:32), ou ao "bom sexo". Os erotismos das chacretes são domesticados através dos recursos audiovisuais disponíveis. Ele se insinua, é sutil, mas a tensão sexual nunca é abertamente exibida. Afasta-se com isso do dito "pornográfico", supostamente recorrente na imprensa alternativa, chamada de "apelativa", em que as poses, os ângulos e as formas de disposição dos corpos são considerados obscenos por exibirem situações de libidinagem, de prazer sexual, de masturbação, ou mesmo cenas de sexo reais, sem subterfúgios.

Poderíamos, assim, confirmar que as atividades das chacretes apontam para um uso instrumental da ordem sexual vigente, uma ativação de nossas normas sexuais, com fins e propósitos específicos de sucesso profissional e financeiro, bem como de autoestima, de valorização de si por meio da fama. Atentar para a agência das chacretes no trabalho por elas desempenhado é levar em conta uma série de aspectos econômicos, políticos e culturais muitas vezes negligenciados sob o rótulo de "serviço oriundo da opressão e dominação masculina".

Todavia, o caráter comercial amaina muitas das subversões que existem nas atividades profissionais das chacretes. Antes de deliberadamente confrontarem tabus sexuais e morais, elas são gestadas segundo as lógicas da indústria cultural, muito preocupada com a "recepção" das jovens nos lares brasileiros, buscando "não chocar" comportamentos pudicos. Produzem um erotismo que deve ser aceitável, palatável, pouco crítico. Mesmo que ressignificadas aqui ou acolá, existem convenções nos atos das chacretes que não têm nada de transgressor, sem falar no conjunto de normas e controles morais ao qual estão submetidas suas sexualidades. Leite Júnior (2006:64) afirma que o mais frequente - em termos de pornografia e erotismo no âmbito da indústria cultural, portanto, nas lógicas mainstream de massificação e disseminação de ideias sobre o sexo - é que estes erotismos se tornem a "expressão da uniformização dos desejos e da padronização dos prazeres" no âmbito comercial, a fim de facilitar a entrada das chacretes no circuito da produtividade capitalista. Neutraliza-se assim qualquer rusga ou crítica maior que os comportamentos das dançarinas poderiam ensejar na sociedade como um todo através de suas exibições na TV, apagando de variadas maneiras qualquer aproximação delas com o "pornográfico" e/ou com a prostituição, por exemplo.

Paradoxalmente, as práticas das chacretes permitem movimentos que garantem certas ressignificações de convenções sobre o sexo, ao mesmo tempo em que um conjunto de dispositivos instaura-se a fim de regrar, controlar e canalizar tais sensibilidades a princípio pouco tradicionais. Perlongher diz 
que nos "espaços de circulação desejantes", por mais que corpos e afetos ponham-se a arder e desestabilizem hegemonias, há sempre forças das mais variadas origens que se instauram "de modo a evitar, esmagar ou neutralizar os perigos da fuga" (Perlongher 2008:250). Procuramos demonstrar ao longo deste artigo o quanto é possível, no contexto mais mainstream da indústria cultural, perseguir essa duplicidade que abarca lugares até então impensáveis para a incitação das sensibilidades eróticas, ao mesmo tempo em que limites são configurados a fim de canalizar tais desejos provocadores.

Nesse sentido, ao realizar um estudo de personalidades e sensibilidades femininas que poderiam ser consideradas como o baixo escalão das classes artísticas e mesmo a escória do que há de pior na indústria cultural brasileira, procurei justamente ressaltar e mesmo engrandecer, na medida do possível, a importância dessas mulheres na consolidação de um mercado de entretenimento e erótico na contemporaneidade. Seguindo aquilo que Corrêa (2003:22) também constatou ao estudar a trajetória de antropólogas brasileiras hoje um tanto desconhecidas para a maioria dos especialistas, o que começou a ficar claro para mim ao longo de minha pesquisa é que o que rotineiramente é chamado de personagens secundários, supérfluos, de uma determinada cena artístico-cultural teve tanta ou mais importância na sua construção e consolidação do que os ditos personagens principais, aqueles que, como Chacrinha, parecem ser os únicos a se apossar dos louros da glória.

Este artigo buscou também subverter as memórias oficiais da televisão e trazer à tona as mais subterrâneas, aquelas que pouco ou quase nenhum espaço têm para estar em nosso dia a dia. Como bem disse Pollak (1989:8), "distinguir entre conjunturas favoráveis ou desfavoráveis das memórias marginalizadas é de saída reconhecer a que ponto o presente colore o passado". É constatar também, por essa mesma perspectiva, que os longos silêncios sobre tais tempos passados longe de conduzirem ao esquecimento generalizado geram, na verdade, as resistências que se impõem ao se fazerem presentes diante do excesso de oficialidades. É quando certas memórias canalizadas e um tanto "esterilizadas", diria o mesmo autor, revoltam-se e afirmam-se a partir de um sentimento de absurdo e abandono.

O movimento das memórias subterrâneas das chacretes fica claro a partir dos relatos de Marina, tecidos ao longo de minha pesquisa de campo com as chacretes. Com eles pretendo encerrar este artigo. Segundo Marina, o fato de não estar hoje ocupando os espaços artísticos mais prestigiados liga-se à sua extrema competência, e não à falta de qualidades. Poucos campos artísticos fariam hoje justiça ao seu talento. O verdadeiro artista, o maior, é aquele que sofre com as rasteiras desleais dos incompetentes, dos fracos e sem talento, que se reproduzem e ajudam uns aos outros a se manterem nos 
espaços privilegiados de trabalho. Marina vê sua trajetória como a de uma artista "ingênua", sem "maldades", ou mesmo um tanto "burra" por se fechar para as negociações do bas fond artístico. A causa real de seu esquecimento hoje não é a falta de qualidade no trabalho artístico que executa ainda nos dias de hoje de maneira esparsa, mas sim o incômodo que gerou desde a tenra idade entre seus pares devido à sua extrema competência.

Eu era burra, burra mesmo. Não sabia aproveitar a fama, deitar na cama, como todo mundo faz. A verdade era essa: eu era burra. Inocente demais. Não burra. Eu não me considero burra. Porque eu nunca deixei ninguém me pisar. Eu era inocente, sabe? Não tinha aquela maldade. Tanto é que quem falou isso foi o Lúcio Mauro. Ele virou e falou assim: "Essa aí vai nadar, nadar e morrer na praia". Aí o cara falou assim: "Por quê?". "Boa demais!". Quer dizer, eu era boa demais! Tanto é que me passaram a perna várias vezes. Eu não sabia mentir. Eu não tinha noção de que tinha que mentir para poder... Ainda mais no meio artístico, pô? No meio artístico é um comendo o outro. Eu não tinha essa maldade, eu não tinha essa experiência. Eu estava num ninho de cobras e não sabia onde é que estava. E sobrevivi pelo meu talento, pelo meu trabalho, pela minha perseverança. Eu andava mais pedindo trabalho do que trabalhava. Você anda mais pedindo trabalho o mês inteiro, para poder fazer um trabalho às vezes por mês. Até no carnaval eu nunca gostei de ficar no meio da multidão. Eu sempre subia numa mesa para me destacar. Eu sempre subia no palco, entendeu? Eu nunca gostei de ficar lá no meio da muvuca, nunca.

"Boa demais!". De forma enérgica, mas ao mesmo tempo resignada, repleta de desesperanças, Marina percebe-se vítima de um sistema que não soube reconhecer o seu talento, um brilho que há anos se revela para a concorrência e que, em decorrência, sempre conseguiu boicotá-la. No "ninho de cobras" que é o mundo artístico, Marina procurou mais trabalho do que efetivamente trabalhou. Sofreu e ainda sofre todas as intempéries da grande artista não reconhecida pelos próprios companheiros. Lembrá-la é, ao mesmo tempo, resistir. 


\section{Notas}

${ }^{1}$ Chacrinha é considerado um dos maiores apresentadores e comunicadores da televisão brasileira. Sua trajetória teve início no rádio, mas o sucesso maior foi mesmo quando começou a comandar programas de auditório, como a "Buzina do Chacrinha" e a "Discoteca do Chacrinha", em diferentes emissoras do país. Chacrinha morreu no ano de 1988, mas até hoje é lembrado por suas originalidade e capacidade de "comandar as massas", como lembra a canção de Gilberto Gil, "Aquele abraço".

${ }^{2}$ Sabe-se que o sexo comercial tem dado lugar a uma imensa indústria. Assim, seguindo Piscitelli (2005:7), entende-se aqui por mercado do sexo todas as atividades ligadas direta ou indiretamente à oferta e à procura de bens e/ou serviços articulados com o sexo, como a prostituição, os trabalhos desempenhados por diversas pessoas em bordéis, boates, bares, saunas, linhas telefônicas, casas de massagem, motéis, cinemas, assim como as revistas e as publicações pornôs, filmes e vídeos eróticos ou de sexo explícito etc. Diante da diversidade do mercado sexual, este artigo concentrou-se nesta última vertente citada, isto é, aquela ligada à imprensa e às atividades da indústria cultural mainstream que, em certa medida, tematizam o sexo em suas produções, tornando-o um produto de consumo.

${ }^{3}$ Butler $(2002,2003)$ vem problematizando em seus mais variados trabalhos a ideia de que há uma coerência entre desejos, práticas, corpos, comportamentos e identidades, colocando em questão a ligação que acreditamos ser necessária entre tais aspectos e as causalidades que um provocaria sobre o outro. Para ela, as "identidades inteligíveis" seriam aquelas cujas coerência e estabilidade dessa tríade são facilmente identificáveis. As instabilidades e as incoerências são constantemente renegadas nesse sistema de inteligibilidade, movimento este que está por trás de expressões como "corpos que importam" e "abjeção". A identificação imediata entre sexo, gênero, desejo e prática sexual seria o efeito de uma prática reguladora que pode ser identificada como "heteronormatividade" ou "matriz heterossexual", uma relação de poder socialmente estabelecida e compulsória que privilegia a heterossexualidade em detrimento de outras orientações sexuais, e com a qual todas e todos se vinculam cotidianamente.

${ }^{4}$ Cabe destacar que realizei também um levantamento da revista Amiga no acervo da Biblioteca Nacional, tendo como base o corte temporal de 1970 a 1975, algo que me permitiu um panorama sobre as chacretes num importante periódico da época, comparando assim como cada uma delas se inseria nesse contexto, quem mais se destacava, quem era pouco comentada etc. A revista Amiga TV Tudo! era editada pelas Organizações Bloch e circulou no país a partir de maio de 1970, portanto, bem no momento de ascensão da indústria cultural televisiva. Ela é considerada a primeira revista que se dedicou exclusivamente a cobrir a programação brasileira, documentando também a vida de seus principais artistas, feito inédito para uma imprensa que ainda se voltava para os produtos midiáticos estrangeiros, como o cinema americano e suas "divas". 
${ }^{5}$ Mais detalhes sobre aquilo que nomeei de performance de superfêmea em Bispo (2012, 2013, 2014).

${ }^{6}$ Assim McClintock (2010:19-20) apresenta o seu plano de pensar as articulações do imperialismo na África do Sul com os temas do gênero, da raça e da classe, indicando-nos que tais marcadores não podem ser pensados de maneira estanque, mas sim em intersecção, como buscamos fazer neste artigo: "Aqui, então, gênero não é só uma questão de sexualidade, mas também uma questão de subordinação do trabalho e pilhagem imperial; raça não é só uma questão de cor de pele, mas também uma questão de força de trabalho, incubada pelo gênero. Apresso-me a acrescentar que não quero implicar que esses domínios são redutíveis ou idênticos entre si; em vez disso, existem em relações íntimas, recíprocas e contraditórias".

${ }^{7}$ Veja, sem data e número, p. 82 (acervo pessoal de Índia Potira).

${ }^{8}$ Essa é uma discussão que constitui parte do pensamento brasileiro há muito tempo, não havendo nenhuma razão aqui para destrincharmos tais reflexões. Deixo um trecho das influentes reflexões de Oracy Nogueira sobre o "preconceito de marca" brasileiro, caracterizado pela importância dada em suas manifestações ao fenótipo e à aparência racial dos indivíduos inseridos num contexto interativo: "Assim, a concepção de branco e não branco varia, no Brasil, em função do grau de mestiçagem, de indivíduo para indivíduo, de classe para classe, de região para região" (Nogueira 1985:80).

${ }^{9}$ Diário de Notícias, 9 de novembro de 1973, p. 15 (acervo pessoal de Índia Potira).

${ }^{10}$ Mais detalhes em Kehl (1986:244) e Mira (1995:38).

${ }^{11}$ Pontes (2004) notou que a magreza de Cacilda Becker lhe permitiu encenar inúmeras peças teatrais, graças à burla que as convenções teatrais permitem, representando os mais diferentes personagens ao longo da carreira. Todavia, para o cinema, Cacilda foi considerada pessoa inapropriada, "antifotogênica" e de "ossos expostos" (Pontes 2004:250).

${ }^{12}$ Homem, n. 27-B (edição especial), p. 7 (acervo da Biblioteca Nacional).

${ }^{13}$ Informações escritas por fãs e admiradores das chacretes, retiradas da comunidade do orkut intitulada "Profile Chacretiano". Em: http://www.orkut.com.br/Mai n\#Profile?uid=16105467158100173169.

${ }^{14}$ Homem, n. 27-B, p. 8, 1980, edição especial (acervo da Biblioteca Nacional).

${ }^{15}$ Movimento organizado por políticos americanos do Partido Republicano e lideranças religiosas oriundas das mais variadas vertentes. Tinha como pretensão impor uma agenda que priorizasse temas, medidas e tentativas de alteração ou criação de leis ligadas, por exemplo, à criminalização do aborto, à extensão de direitos básicos a homossexuais, à atuação da mulher na esfera pública, entre outros assuntos. 


\section{Referências bibliográficas}

ALMEIDA, Heloisa Buarque de. 2012. "Trocando em miúdos: gênero e sexualidade na TV a partir de Malu Mulher". Revista Brasileira de Ciências Sociais, 27(79):125-138.

BARBOSA, Florinda \& RITO, Lúcia. 1996.

Quem não se comunica, se trumbica. Rio de Janeiro: Globo.

BISPO, Raphael. 2012. "Gênero e carreiras artísticas na emergente indústria cultural brasileira". Comunicação e Sociedade, 21:79-94.

- 2013. Senhoras do Rebolado: carreiras artísticas e sensibilidades femininas no mundo televisivo. Tese de Doutorado, Museu Nacional-UFRJ. - 2014. "Por uma etnografia dos artistas populares: reflexões sobre personas midiáticas e biografias de celebridades". In: S. Kofes \& D. Mânica (orgs.), Etnografia e biografia: experiências com as diversas grafias sobre a vida social. Rio de Janeiro: Lamparina. pp. 239-259. BUTLER, Judith. 2002. Cuerpos que importan: sobre lós limites materiales y discursivos del "sexo". Paidós: Buenos Aires.

- 2003. Problemas de gênero: feminismo e subversão da identidade. Rio de Janeiro: Civilização Brasileira.

CORRÊA, Mariza. 1996. "Sobre a invenção da mulata". Cadernos Pagu, 6/7:35-50. - 2003. Antropólogas e antropologia. Belo Horizonte: UFMG.

DE LAURETIS, Teresa. 1994. "A tecnologia do gênero". In: H. B. de Hollanda (org.), Tendências e impasses: o Feminismo como crítica da cultura. Rio de Janeiro: Rocco. pp. 206-242.

DÍAZ-BENíTEZ, Maria Elvira. 2010. Nas redes do sexo: bastidores do pornô brasileiro. Rio de Janeiro: Zahar.
GIACOMINI, Sonia Maria. 1992. "Aprendendo a ser mulata: um estudo sobre a identidade da mulata profissional". In: A. O. Costa \& C. Bruschini (orgs.), Entre a virtude e o pecado. São Paulo: Rosa dos Tempos/ Fundação Carlos Chagas. pp. 213-246. - 2006a. A alma da festa: família, etnicidade e projetos num clube social da zona norte do Rio de Janeiro O Renascença Clube. Belo Horizonte: Editora UFMG. . 2006b. "Mulatas profissionais: raça, gênero e ocupação". Revista Estudos Feministas, 14(1):85-101.

GREGORI, Maria Filomena. 2003. "Relações de violência e erotismo". Cadernos Pagu, 20(1):87-120.

. 2012. "Erotismo, mercado e gênero: uma etnografia dos sex shops de São Paulo". Cadernos Pagu, 38(1):53-97. KEHL, Maria Rita. 1986. "Eu vi um Brasil na TV". In: I. Simões et al. (orgs.), Um país no ar: história da TV brasileira em três canais. São Paulo: Brasiliense/ Funarte. pp. 167-323.

KOFES, Suely. 2001. Uma trajetória, em narrativas. Campinas: Mercado das Letras.

LEITE JÚNIOR, Jorge. 2006. Das maravilhas e prodígios sexuais: a pornografia "bizarra" como entretenimento. São Paulo: Annablume/Fapesp.

MARTINEZ, Fabiana Jordão. 2004. "Experiência e (hiper)corporalidade entre modelos profissionais". Cadernos do IFCH, 31:211-234.

McCLINTOCK, Anne. 2010. Couro imperial: raça, gênero e sexualidade no embate colonial. Campinas: Unicamp. MIRA, Maria Celeste. 1995. Circo eletrônico: SBT. São Paulo: Olho D'Água/ Loyola. 
NOGUEIRA, Oracy. 1985. Tanto preto quanto branco: estudos de relações raciais. São Paulo: T. A. Queirós.

PERLONGHER, Néstor. 2008. O negócio do michê: a prostituição viril em São Paulo. São Paulo: Fundação Perseu Abramo. PISCITELLI, Adriana. 2002. "Exotismo e autenticidade: relatos de viajantes à procura de sexo". Cadernos Pagu, 19:195-231. . 2004. "Entre a Praia de Iracema e a União Europeia: turismo sexual internacional e migração feminina". In: A. Piscitelli; M. F. Gregori \& S. Carrara (orgs.), Sexualidades e saberes: convenções e fronteiras. Rio de Janeiro: Garamond. pp. 283-318.

2005. "Introdução: gênero no mercado do sexo". Cadernos Pagu, 25:7-23. . 2007. "Corporalidades em confronto: brasileiras na indústria do sexo na Espanha". Revista Brasileira de Ciências Sociais, 22(64):17-32.

_ 2011. "Amor, apego e interesse: trocas sexuais, econômicas e afetivas em cenários transnacionais". In: A. Piscitelli, G. O. Assis \& J. M. N. Olivar (orgs.), Gênero, sexo, amor e dinheiro: mobilidades transnacionais envolvendo o Brasil. Campinas: Unicamp/ Pagu. pp. 537-582.

POLLAK, Michael. 1989. "Memória, esquecimento, silêncio". Estudos Históricos, 2(3):3-15.

PONTES, Heloisa. 2004. "A burla do gênero: Cacilda Becker, a Mary Stuart de Pirassununga". Tempo Social, 16(1): 231-262.

· 2009. “Beleza Roubada: gênero, estética e corporalidade no teatro brasileiro". Cadernos Pagu, 33:139-166.

RUBIN, Gayle. 1984. “Thinking sex: notes for a radical theory of the politics of sexuality". In: C. Vance (ed.), Pleasure and danger: exploring female sexuality. Boston and London: Routledge/ Kegan Paul. pp. 267-319.
VANCE, Carole. 1984. "Pleasure and danger: toward a politics of sexuality". In: C. Vance (ed.), Pleasure and danger: exploring female sexuality. Boston and London: Routledge/ Kegan Paul. pp. 1-27. 


\section{Resumo}

Durante os anos 1970 e 1980, um conjunto de dançarinas sensuais, as chacretes, ganhou destaque na televisão. Além de auxiliar o apresentador Chacrinha em programas de auditório, compunha paralelamente um crescente mercado erótico. Este artigo procura dar um passo atrás no auge do estrelato e compreender como as dançarinas chegavam a esse nicho de mercado. A ideia é analisar os processos de seleção a que foram submetidas, enfocando principalmente os requisitos necessários para se tornarem uma dessas mulheres do show business televisivo. O fio argumentativo central do artigo é que gêneros, corpos e erotismos se entrelaçam na construção da figura televisiva dessas mulheres e se explicitam nos processos que regulam o recrutamento e a exposição de suas imagens. A importância dada à estética corporal das chacretes acionava assim uma plêiade variada de marcadores sociais da diferença (como o gênero, a idade, a cor/raça, a sexualidade, a classe etc.) que, quando em interseção, operavam como critérios de distinção, tornando alguns corpos mais desejáveis do que outros, sendo alguns deles alvo de recrutamento e atenção e outros não, nesse contexto das artes populares.

Palavras-chave Gênero, Corpo, Erotismo, Mídia, Carreiras artísticas.

\section{Abstract}

During the 1970s and 1980s, a group of erotic dancers known as the Chacretes gained notoriety in Brazilian television. As well as being stagehands for the host Chacrinha during his talk show, they were also players in a growing erotic market. This article takes a step back from the pinnacle of their stardom to analyse how these dancers came to occupy this market niche. It aims to analyse the selection process these dancers were submitted to, focusing mainly on the requirements for becoming show business women on TV. Its main argument is that genders, bodies and eroticisms become enmeshed in the construction of the television image of these women, and that they are made explicit in the processes that regulate the recruitment and exposition of their images. The emphasis on the bodily aesthetic of the Chacretes trigger a varied constellation of social markers of difference (such as gender, age, colour/ race, sexuality, class, etc.), all which intersect as a function of criteria of distinction, making some bodies more desirable than others, as some became the objects of recruitment and attention while others do not.

Key words Gender, Body, Eroticism, Media, Artistic careers. 